\title{
Teatr w XXI wieku - ku nowym definicjom ${ }^{*}$
}

ABSTRACT. Kosiński Dariusz, Teatr $w$ XXI wieku - ku nowym definicjom [Theatre in $21^{\text {ta }}$ Century - Towards New Definitions]. „Przestrzenie Teorii” 3/4, Poznań 2004, Adam Mickiewicz University Press, pp. 215-225. ISBN 83-232-1454-9. ISSN 1644-6763.

The article Theatre in $21^{\text {st }}$ Century - Towards New Definitions deals with the problem of narrow understanding of theatre art that dominates not only common thought but also the scientific practise of Polish theatrologists. This traditional definition is based on five elements: theatrical illusion, close connection with drama, dramatic character, stage box and space/time community between actors and spectators. During the development of the theatre in $20^{\text {th }}$ century this distinctive features were disproved by the reformers and experimenters. At the same time such theatre categories as performance, role, stage etc. were widely used to describe "theatre of everyday life". In the last decades of the $20^{\text {th }}$ century the new field of science - the performance studies emerged. The reaction of the theatrology was one of defending the traditional borders and neglecting all that was different from the conventional theatre by calling it "paratheatrical" or "alternative". In the author's opinion this notion is false and causes real losses for the discipline, so he proposes to open the borders of theatrology by taking different activities into account. But it doesn't mean the full acceptation of performance studies' terminology and point of view, because there is a danger of substituting the term "theatre" by the wider term "performance". And the difference between one and the other seems to be important, because the theatre is a kind of consciously created performance which is marked as such. The ways and methods of this marking depend on the cultural and historical context, so they change in space and time. Only the exact act of marking is universal. It means, that in the scientific practise there is no universal group of definite "theatre factors". The definitions of theatre are always to be reached and that's why "towards" is the most important word in the article's title.

Mawia się, że przedstawienie to obrazy i metafory. Jednego jestem pewien - że tak nie jest.

Eugenio Barba

W tytule tego tekstu - niekoniecznie najszczęśliwszym i w pełni zadowalającym jego autora - jest jedno słowo szczególnie ważne i - jak mi się wydaje - trafne. To przyimek „ku”, wiążący się z wyruszeniem dokądś, ze stanem otwarcia i dążenia do celu, który wcale nie musi być określony, a nawet - kto wie? - może wcale nie istnieje. Chciałbym za-

* Prezentowany tekst jest wersją referatu wygłoszonego na konferencji „Teatr - media - kultura" zorganizowanej z okazji Jubileuszu 50-lecia pracy naukowej prof. dr hab. Eleonory Udalskiej przez Zakład Wiedzy o Teatrze Instytutu Nauk o Kulturze Uniwersytetu Sląskiego w dn. 16-17 kwietnia 2004 roku w Ustroniu. 
proponować tak właśnie pojmowany zwrot ku... nowym definicjom, czy też - może lepiej - nowemu rozumieniu teatru.

Skoro mowa o zakładanym a nieznanym i niepewnym „nowym” rozumieniu teatru, to nie od rzeczy będzie na początek przyjrzeć się rozumieniu znanemu, co wcale nie znaczy „pewnemu”. Chodzi o rozumienie potoczne i stereotypowe zarazem, które swój największy triumf święciło - jak się zdaje - w krytyce i myśli teatralnej XIX wieku, stając się następnie podstawą nienaukowego, ale powszechnie obecnego w naszym kręgu kulturowym pojęcia „teatru właściwego”, przeciwstawianego „teatrowi alternatywnemu" czy te $\dot{z}$, innemu teatrowi”. Rozumienie to jest związane przede wszystkim z teatrem realistycznym, dążącym do iluzji, do stworzenia takiego obrazu rzeczywistości, który dana widownia jest skłonna uznać za prawdziwy, czyli zgodny z jej doświadczeniem i wyobrażeniami. Oczywiście realistyczność tego typu teatru nie jest wartością stałą - zmienia się ona w zależności od czasu, środowiska, kontekstu itp. Stałe jest natomiast wymaganie, by teatr ukrywał swą „sztuczną" naturę, by aktorzy nie grali, lecz byli postaciami, by scena była oddzielona od widzów nie tylko przez podzial przestrzeni, ale także mentalnie („czwarta ściana”). Od całości i nienaruszalności osiąganego w ten sposób „złudzenia widzów, które im każe zapominać, że patrzą na kopię natury [...]"1 uzależniano wartość przedstawienia i możliwość spełniania przez nie wszelkich funkcji społecznych, od rozrywkowych po edukacyjne czy polityczne.

Stworzenie iluzji teatralnej wymagało przy tym współdziałania kilku czynników. Pierwszym z nich była scena pudełkowa - szczególne ukształtowanie przestrzeni, wiążące się z określonymi koncepcjami antropologicznymi i filozoficznymi ${ }^{2}$. Drugim, rówrie ważnym - realizm gry aktorskiej, której celem stało się stworzenie postaci scenicznej spełniającej aktualne wymogi prawdopodobieństwa, przy czym zazwyczaj obejmowały one także życie wewnętrzne wykonawcy, a w szczególności „przejęcie się" losami i doświadczeniami danego bohatera.

Oba te czynniki główne, wspierane jeszcze przez dekoracje, kostiumy, oświetlenie, technikę sceniczną i widowiskowe tricki, powinny według rekonstruowanego tu stereotypu - pozostawać w ścisłym związku z literaturą, a w szczególności z dramatem, który jest źródłem obrazu świata ukazywanego na scenie. Teatr bowiem ma mierzyć się z rzeczywistością nie bezpośrednio, ale poprzez dopełnianie i/lub modyfikowanie dzieła cudzego. W swej skrajnej postaci koncepcja taka wiedzie do stwierdzenia, że teatr ,jest dopełnieniem plastycznym jednej gałęzi po-

${ }^{1} \mathrm{H}$. Meciszew ski, Uwagi o teatrze krakowskim, Kraków 1843, s. 144-145.

2 Zob.: D. Ratajczak, Przestrzeń $w$ dramacie $i$ dramat $w$ przestrzeni teatru, Poznań 1985, s. 11-66. 
ezji"3, będącego podstawą zespołu przekonań, które Zbigniew Przychodniak nazwał „literacką koncepcją teatru”4. Nawet jednak w swej wersji złagodzonej, dopuszczającej pewien stopień ingerencji artysty teatru w materię działa dramatycznego, rekonstruowany stereotyp widzi $\mathrm{w}$ teatrze „dziedzinę sztuki polegającą na realizowaniu scenicznych utworów literackich"'.

Inna grupa oczywistych dla stereotypu warunków zaistnienia teatru związana jest $\mathrm{z}$ obecnością widzów. Działanie teatralne podejmowane jest bowiem przez jedną grupę ludzi - artystów - ze względu na drugą grupę - publiczność. Jeśli jej nie ma, teatr, jako zjawisko pojawiające się pomiędzy, nie powstaje. Przyjmuje się przy tym zazwyczaj, że publiczność musi być obecna $\mathrm{w}$ tym samym czasie i miejscu, co występujący przed nią artyści, jako że teatr jest sztuką żywą, której wartością szczególną jest, choćby potencjalna, możliwość bezpośredniego reagowania na zmiany zachodzące na widowni ${ }^{6}$.

Podsumowawszy to - z konieczności skrótowe - zestawienie, otrzymujemy listę elementów, które w stereotypowym wyobrażeniu decydują o specyfice sztuki teatru. Są to: iluzja, scena pudełkowa, centralna pozycja sztuki aktorskiej, ścisły związek z literaturą dramatyczną, a w szczególności z postacią, oraz związek z publicznością, zakładający, że scena i widownia tworzą wspólnotę czasowo-przestrzenną.

Jeśli teraz z perspektywy tak zrekonstruowanego stereotypu spojrzymy na niedawno zakończone dzieje teatru XX-wiecznego, to okaże się, że stanowią one ciąg „rewolucji scenicznych”, stawiających sobie za cel obalenie przekonania o nienaruszalności wyżej wymienionych elementów definicyjnych. Pierwszym, jeszcze XIX-wiecznym, celem ataku stała się zależność teatru od literatury. $\mathrm{Na}$ ironię zakrawa fakt, że pierwsi do boju wyruszyli literaci, dążący do obalenia panowania aktorek i aktorów, oskarżanych o zajęcie miejsca należnego wyłącznie pisarzom jako właściwym twórcom dramatu utożsamianego z przedstawieniem. Sojusznikami literatów $\mathrm{w}$ walce $\mathrm{z}$,gwiazdorstwem i aktoromanią" mieli być reżyserzy, wynajęci dla zaprowadzenia porządku (czytaj: zespołowości) i godnego reprezentowania interesów dramaturgów. Jak to z najemni-

3 J. Kotarbiński, Kilka stów o istocie sztuki aktorskiej, „Przegląd Tygodniowy” 1873 , nr 5, s. 406-407.

${ }_{4}$ Zob.: Z. Przychodniak, $U$ progu romantyzmu. Przemiany warszawskiej krytyki teatralnej 1815-1825, Wroclaw 1991, s. 55-56.

${ }^{5}$ Stownik języka polskiego, red. M. Szymczak, Warszawa 1981, t. III, s. 485.

6 Wobec wspomnianego wyżej wyobrażenia o „czwartej ścianie” zakrawa to na pewien paradoks, ale w rekonstruowanym wyobrażeniu rzeczywiście obecne są oba elementy oddzielenia i wspólnoty. Napięcie między nimi wiedzie do specyficznej przyjemności płynącej z oglądania spektaklu, będącego w tym kontekście aktem podglądania, zapewniającego widzowi i bezpieczeństwo, i poczucie wyższości. 
kami bywa, po obaleniu dyktatury aktorskiej (w istocie utrzymującej się pod koniec stulecia na bardzo kruchych podstawach) reżyserzy $i$ inscenizatorzy sami przejęli władzę i nie oglądając się na dramatopisarzy, ogłosili erę „artystów teatru” i jego „reteatralizacji”. Oznaczało to w pierwszej kolejności zwrot przeciwko dominacji literatury i deklarację autonomii teatru. W ciągu kilkudziesięciu lat sztuka ta wywalczyła sobie prawo do wykorzystywania materiału literackiego (niekoniecznie dramatycznego) w taki sposób, jaki jest dla niej najbardziej dogodny, zaś demontaż literackiej koncepcji teatru doprowadził ostatecznie do powstania przedstawień, które $\mathrm{w}$ ogóle obchodzą się bez literatury (co nie znaczy - bez słowa).

Drugim obok zależności od literatury celem ataku XX-wiecznych reformatorów teatralnych stała się oczywiście teatralna iluzja związana $\mathrm{z}$ realizmem. Strategii i taktyk wykorzystano $\mathrm{w}$ tej batalii bardzo wiele i bardzo różnorodnych, od prób powołania teatru obdarzonego skutecznością rytualnego aktu, przez bezpośrednie interweniowanie w materię życia (zwłaszcza politycznego), po dążenie do ukazania w przedstawieniu samego siebie. Wszystkie te działania miały nie tylko zniszczyć iluzję teatralną, ale wręcz doprowadzić do demontażu samej zasady naśladowania działania. Z próbami tymi wiązało się oczywiście dążenie do przedefiniowania przestrzeni teatralnej i rozbicia „scenicznego pudełka”, co doprowadziło do powstania teatrów działających z zasady $\mathrm{w}$ „miejscach nieteatralnych"?.

Część ataków na iluzję skierowana została także na postać teatralną jako szczególną odmianę fikcyjnego „tworu ludzkiego powstałego na obraz i podobieństwo człowieka"8. Usiłowano ją przepędzić ze sceny, wykorzystując idealizowaną bezpośredniość dzialania konkretnej osoby występującej we własnym imieniu, ale - jak się wydaje - skuteczniejsza okazała się metoda dekonstrukcji postaci jako pewnej całości. To ona właśnie - w wykonaniu Richarda Foremana czy The Wooster Group posłużyła Elinor Fuchs jako argument pozwalający na ogłoszenie „śmierci postaci scenicznej” i stwierdzenie, że „bohater, charakter”, który w okresie romantyzmu ,zepchnął na drugi plan akcję sceniczną, teraz [...] sam znika z pola widzenia"9. Nawet bez posuwania się do tak radykalnych stwierdzeń zauważyć trzeba, że w teatrze wczorajszym i dzisiejszym coraz większe znaczenie zyskuje sztuka metamorfozy, przeciwstawiana umiejętności tworzenia całościowego i jednolitego charakteru. Aktor coraz częściej musi być „zwielokrotniony”, musi - że użyję opiso-

7 Ten paradoksalny zwrot pochodzi z tytułu zbioru artykułb́w opublikowanego w roku 1998 pod redakcją Juliusza Tyszki, Teatr $w$ miejscach nieteatralnych, Poznań 1998.

${ }^{8}$ Z. Raszewski, Teatr $w$ świecie widowisk, Warszawa 1991, s. 61.

9 E. Fuchs, Śmierć postaci scenicznej, przeł. P. Konic, „Dialog” 1989, nr 11-12, s. 123. 
wego wyrażenia Włodzimierza Staniewskiego - być jak rycerz na polu walki, „który jednocześnie walczy z wieloma przeciwnikami, więc jego energia, jego obecność musi być zwielokrotniona, zmienna"10. Działań poszczególnych aktorek i aktorów w wielu przypadkach nie da się zrozumieć jako działań jednej postaci, czasem zaś kategoria postaci w ogóle nie ma w dzisiejszym teatrze zastosowania.

Jakby tego było mało, rozwój technologii doprowadził do pojawienia się zjawisk, które nazywane są teatrem, a nie zachowują tak - wydawałoby się - naturalnego dla tej dziedziny elementu definicyjnego jak jedność przestrzenno-czasowa aktu kreacji i recepcji. Na jej rozbiciu właśnie polega istota problemu teatru telewizji, teatru rejestrowanego, montowanego i odtwarzanego, a więc oglądanego w innym czasie niż czas powstania. Rozbicie owej jedności stanowi też jedną z zasad trwających już od kilkunastu lat eksperymentów z teatrem wirtualnym czy też teatrem internetowym. Wśród jego rozlicznych form jest i taka, która polega na tworzeniu przedstawień łączących $w$ cyberprzestrzeni działania odbywające się w kilku różnych miejscach fizycznych, często też dopuszczających interakcje ze strony internautów (np. Electronic Disturbance zespołu Troika Ranch z roku $1996^{11}$ ). Z racji ograniczeń technologicznych teatr internetu wciąż pozostaje w fazie eksperymentalnej, ale już pierwsze próby wskazują na to, że stanowić on będzie kolejny argument na rzecz koniecznej redefinicji jednego z podstawowych wyznaczników teatru - czasoprzestrzeni.

Być może najbardziej zaskakującym owocem XX-wiecznych poszukiwań teatralnych jest powstanie takich dziel, które w zasadzie nie są przeznaczone do oglądania, nie powstały ze względu na widzów i mogą się znakomicie bez nich obejść. Chodzi o szczególną formę treningu ukształtowaną najpierw w Teatrze Laboratorium, a następnie przejętą i rozwiniętą np. przez Odin Teatret Eugenia Barby. Ćwiczenia, nie związane bezpośrednio $\mathrm{z}$ potrzebami przedstawienia, ale służące psychofizycznemu rozwojowi poszczególnych członków zespołu, zamieniły się w działania mające określoną strukturę zrodzoną z dynamicznych napięć między elementami stałymi a improwizowanymi. Oglądane, kojarzą się nie $\mathrm{z}$ próbami czy treningiem, ale $\mathrm{z}$ rodzajem tańca czy teatru ruchu. Ich twórcy, komentując własną pracę, bardzo często mówią o nich jako o „partyturze działan”, a nawet przypisują im określone znaczenia, uznając za rodzaj „przedstawienia dla samego siebie” ${ }^{2}$.

$10 \mathrm{~W}$. Staniewski with A. Hodge, The Hidden Territories. The Theatre of Gardzienice, London-New York 2004, s. 100 (cytat w moim przekładzie).

11 Informacje o internetowych działaniach Troika Ranch zawdzięczam Agacie Otrębskiej, piszącej pod moją opieką pracę magisterską na temat tej grupy.

12 Por. wypowiedź Reny Mireckiej w filmie J. Domagalika Pełen guślarstwa obrzęd świętokradzki... O Teatrze Laboratorium Jerzego Grotowskiego, 1979. 
W wyniku wszystkich wymienionych tu pokrótce działań podważona została oczywistość punktów oparcia stereotypowego i potocznego zarazem rozumienia teatru, które zrekonstruowano na początku. Nie znaczy to oczywiście, że taki teatr przestał istnieć. Wciąż przecież funkcjonują sceny i zespoły dążące do stworzenia iluzji rzeczywistości, wykorzystujące $\mathrm{w}$ tym celu coraz to nowsze środki techniczne; wciąż dominującym modelem przestrzeni teatralnej jest scena pudełkowa; wciąż teatr zachodni zajmuje się przede wszystkim wystawianiem dramatu, a pracujący w nim aktorzy są wysoko cenieni za kreowanie fascynujących i „prawdziwych" postaci; wciąż też żywa obecność twórców i publiczności stanowi dla wielu bardzo istotną wartość tej dziedziny sztuki. „Rewolucje sceniczne XX wieku" nie doprowadziły do likwidacji którejś z teatralnych konwencji, ale poszerzyły ich zespół o konwencje nowe, w myśl stereotypu „nieteatralne”. I to właśnie jest zasadniczy problem związany z XX-wiecznymi przemianami - w dziedzinie nazywanej „teatr” pojawiły się zjawiska, które w myśl tradycyjnych definicji do owej dziedziny nie należą, więcej - podważają jej „filary nośne”.

Jakby tego było mało, przemianom w praktyce teatralnej towarzyszyły zmiany w naukach społecznych, których istotę można by ująć jako rozprzestrzenienie się terminologii i metod opisu właściwych teatrologii na dziedziny leżące poza teatrem. Kluczowe znaczenie ma tu oczywiście książka Erwinga Goffmanna Człowiek $w$ teatrze życia codziennego, wydana po raz pierwszy w roku 1959 i wprowadzająca do analizy socjologicznej takie pojęcia jak „występ" (w oryginale performance), rola, scena etc. W ślady amerykańskiego uczonego poszli następni przedstawiciele różnych dyscyplin $\mathrm{z}$ socjologią $\mathrm{i}$ etnologią na czele, stosujący analogie teatralne do badania zjawisk życia społecznego. Bardzo szybko dostrzeżono, że analiza konwencji społecznych przeprowadzana metodami właściwymi wiedzy o teatrze może dostarczyć narzędzi przydatnych do badania zarówno teatru, jak i różnorodnych, leżących poza jego granicami, przejawów życia społecznego. Bodaj najpełniej dowiodła tego Elizabeth Burns w swej książce Theatricality. A Study of Conventions in the Theatre and in Social Life (1972). Tytułowa teatralność stała się pojęciem łączącym teatrologię i inne dziedziny nauki, jawiąc się jako zjawisko poznawalne wprawdzie poprzez badania nad teatrem, ale występujące na obszarze $o$ wiele odeń rozleglejszym.

Zainteresowanie teatralnością pozateatralną, wzbogacone o antropologiczne badania nad rytuałami i grami/zabawami, doprowadziło $\mathrm{w}$ ostatnich dekadach XX wieku do powstania nowej dyscypliny naukowej - performatyki (performance studies), zajmującej się tym, „co ludzie ro- 
bią, gdy podejmują działania"13. Podstawą performatyki jest angielskie słowo performance, rozumiane, zgodnie ze znaczeniem słownikowym czasownika źródłowego to perform, bardzo szeroko, jako każde działanie przebiegające $z$ zachowaniem określonego schematu lub wzorca, w sposób szczególny nastawione na wywarcie wrażenia na obserwatorze ${ }^{14}$. Tak rozumiany performans ${ }^{15}$ występuje we wszystkich niemal dziedzinach ludzkiej aktywności. Ba! - jeden z twórców nowej dyscypliny, Richard Schechner pisze, że $\mathrm{z}$ „punktu widzenia performatyki, jaką proponuję, każde działanie stanowi performans"16, co wiąże się z faktem, że podstawą jego definicji performansu jest pojęcie „zachowanego zachowania" (restored behavior) oznaczające zachowanie przebiegające zgodnie z nabytym, przećwiczonym i odtworzonym wzorem. Według Schechnera, idącego tu za koncepcjami socjologii i antropologii wywodzącymi się m.in. ze słynnego studium Marcela Maussa o kulturowych uwarunkowaniach sposobów używania ciała17, wszystkie ludzkie działania mają charakter "zachowanych zachowañ, a coś takiego jak „zachowanie jednokrotne" po prostu nie istnieje.

Dla nauki o teatrze pojawienie się performatyki ma znaczenie wręcz kluczowe. Oznacza ono bowiem, że metody stosowane przez teatrologów oraz posiadane przez nich umiejętności, zdobyte dzięki analizie przedstawień teatralnych, mogą okazać się niezwykle przydatne do badania niemal każdego typu zjawisk życia społecznego. Wystarczy tylko zmiana perspektywy i umiejętność odkrywania wzorów i konwencji znanych $\mathrm{z}$ teatru, by podjąć badania nad teatralnością życia codziennego, polityki, widowisk kultury masowej, telewizji, sportu, a nawet sztuki kulinarnej, życia erotycznego itp. W świecie, w którym dominuje masowe widowisko, a zamiast mówienia prawdy kreuje się wizerunek, wiedza o teatrze, o rządzących nim prawach i konwencjach stać się może dostarczycielką narzędzi pomagających $w$ zrozumieniu tego, co nas otacza, a także w demaskowaniu iluzji, chcącej uchodzić za rzeczywistość. W tym sensie performatyka jawi się jako szansa na uzyskanie przez wiedzę o teatrze rangi, jakiej nie miała ona bodaj nigdy.

${ }^{13}$ R. Schechner, Performance Studies. An introduction, London-New York, 2002, s. 1. Mój przekład nie oddaje wiernie lakonicznej soczystości oryginalnej formuły: "what people do in the activity of their doing".

${ }_{14}$ Zob.: R. Schechner, Co to jest performans, przeł. T. Kubikowski, „Dialog” 2003, nr 3, s. 128.

15 Spolszczenie zaproponowane przez Tomasza Kubikowskiego. Zob. słowo wstępne do: R. Schechner, Co to jest performans, s. 127.

16 Tamże, s. 137.

17 Zob.: M. Mauss, Sposoby postugiwania się ciałem, w: tegoż, Socjologia i antropologia, Warszawa 1973, s. 538-566. 
Tymczasem dwudziestowieczne tendencje do poszerzania granic teatru, wzmacniane przez coraz silniejsze fale performatyki, wywołały w łonie teatrologii dość zaskakującą reakcję, polegającą na dążeniu do wzniesienia solidnych murów chroniących rubieże dyscypliny. Co zastanawiające, mury te wznoszone są w miejscach bardzo tradycyjnych i strzegą wąskiego, stereotypowego rozumienia teatru. Niekiedy ma to charakter świadomej akcji, będącej konsekwencją określonych przekonań i hierarchii wartości. Tak jest w przypadku książki Zbigniewa Raszewskiego, który $\mathrm{w}$ Teatrze $w$ świecie widowisk zapuszcza się $\mathrm{w}$ dziedziny bliskie performatyce, ale tylko po to, by potwierdzić teoretyczne podstawy deklarowanego na wstępie wąskiego rozumienia teatru, którego anachroniczności autor był świadom ${ }^{18}$. Granice tego rozumienia wytyczają (wyliczam za Krzysztofem Pleśniarowiczem): „wspólny wszystkim widowiskom zamiar wywołania podziwu; czysto teatralny fenomen postaci, wielostopniowej i wielofazowej; celowe podporządkowanie fikcji (ku życiu zwróconej); konieczne dążenie ku związkom ze światem wartości; wreszcie "kryształowa" budowa akcji"19. Poza tak wytyczonym terenem znajduje się nie tylko rytual i teatr do rytualnej skuteczności dążący, ale także happening i performans artystyczny wszelkich odmian oraz wszystkie przedstawienia nierespektujące „struktury kryształu”.

Podjęty przez Zbigniewa Raszewskiego wysiłek zbudowania teoretycznej podstawy własnych przekonań budzi szacunek nie tylko ze względu na odkrycia i inspiracje, które przynosi (także wtedy, gdy - jak Leszek Kolankiewicz na przykład - wchodzi się z Raszewskim w ostry spór), ale i z racji nieukrywania swojego ideologicznego zaplecza. Autor Teatru $w$ świecie widowisk świadomie broni własnego rozumienia teatru, widząc w nim wartość zagrożoną przez współczesne mu tendencje. Taka postawa jest jednak dosyć rzadka. Częściej zdarza się, że deklarowanej otwartości na różnego rodzaju „eksperymenty”, oznaczające w istocie negację tradycyjnych podziałów, towarzyszy przeciwstawna im tendencja do „obrony oblężonej twierdzy” i arbitralnego odsuwania zjawisk problematycznych poprzez odmawianie im miana "teatru”.

Praktyka taka stanowi jakby ciemną stronę szlachetnego dążenia profesora Raszewskiego. Oznacza ona bowiem, że termin „teatr”, pozornie mający znaczenie określenia ścisłego, służy także jako rodzaj tytułu honorowego, na który trzeba zasłużyć, spełniając pewne, przyjęte apriorycznie warunki. Dla przykładu przeczytajmy w tym kontekście początek hasła „parateatr" w Stowniku terminów teatralnych Patrice'a Pavisa. Termin tytułowy objaśniany jest tam jako „rodzaj działalności, która wykorzystuje procedury praktyki teatralnej $\mathrm{w}$ celu stworzenia pewnej

18 Zob.: Z. Raszewski, Teatr $w$ świecie widowisk, Warszawa 1991, s. 11.

${ }^{19}$ K. Pleśniarowicz, Przestrzenie deziluzji, Kraków 1996, s. 112. 
sytuacji czy zdarzenia o charakterze widowiskowym, $\mathrm{z}$ udziałem (lub współudziałem) widzów. Od przedstawienia teatralnego parateatr różni się tym, że jego twórcy nie mają zazwyczaj na celu stworzenia wypowiedzi o ambicjach artystycznych, a ich działania prowadzone są poza istniejącymi instytucjami teatralnymi" 20 . Jest to więc w zasadzie teatr, tyle że nie będący sztuką i dziejący się poza istniejącymi instytucjami. W sytuacji, gdy nie wiadomo, co to takiego sztuka i czym różni się działalność artystyczna od nieartystycznej, jako jedyny punkt oparcia pozostaje instytucja ${ }^{21}$.

We wciąż zmieniającym się świecie, jej trwałość stanowi rzeczywistą wartość, ale nie można jej uznać za akceptowalną podstawę podziału na to, co teatralne, a co tylko „para”. Abstrahując już od arbitralności takiego rozróżnienia, wystarczy uświadomić sobie, że to, co zgodnie z nim znajduje się poza murami twierdzy, jest po prostu zbyt ważne i zbyt rozległe jak na stale lekceważone „pogranicze” czy „alternatywę”. Co gorsza, okopując się w obrębie „starego miasta”, teatrologia sama pozbawia się szansy na stanie się nauką nie tylko atrakcyjną, ale rzeczywiście potrzebną współczesności. Nie ma co się łudzić - teatr rozumiany tradycyjnie jest zjawiskiem coraz bardziej drugoplanowym (co nie znaczy mniej wartościowym!), a większość zagadnień podejmowanych przez badaczy nim się zajmujących ma charakter historyczny. Otwarcie się na nowe rozumienie teatru, uznanie rzekomych aksjomatów za elementy uwarunkowane i ograniczone historycznie i kulturowo, powinno otworzyć przed specjalistami od przedstawień nowe, fascynujące i domagające się opisu tematy i problemy.

Chciałbym być dobrze zrozumiany: postulat otwarcia się na nowe zjawiska nie oznacza rezygnacji z opisywania przeszłości. Zdecydowana większość tego, co napisałem o teatrze, należy do jego historii, dotyczy „staroświecczyzny”. Byłbym więc w sprzeczności z samym sobą, gdybym nagle sugerował jakiś monopol aktualności. Podobnie też jestem jak najdalszy od twierdzenia, że to, co uważa się za mainstream, jest gorsze od „innego teatru”. Wszelkie tego typu wartościowanie jest mi obce i właśnie ze względu na przekonanie o konieczności jego odrzucenia chciałbym, byśmy oduczyli się wykorzystywania słowa "teatr" w charakterze nagro-

20 P. Pavis, Stownik terminów teatralnych, przeł., oprac. i uzupełnieniami opatrzył S. Swiontek, Wrocław-Warszawa-Kraków 1998, s. 343.

21 Za Aldoną Jawłowską definiuję instytucję jako „system reguł postępowania oraz środków organizacyjnych zapewniających realizację jakiś celów społecznych lub zaspokojenie indywidualnych czy też zbiorowych potrzeb" (A. Jawłowska, Więcej niż teatr, Warszawa 1988, s. 176). W przypadku teatru chodzi o system regul związanych ze stereotypowym rozumieniem tej dziedziny sztuki, wzmacnianych przez zasady organizacyjne przedsiębiorstwa teatralnego. Zarówno system reguł, jak i cele oraz zasady organizacyjne „teatru instytucjonalnego" domagają się pilnego i dokładnego opisu. 
dy, której nieprzyznanie oznacza wyrzucenie danego zjawiska poza pole obserwacji naszej dyscypliny. Dotyczy to zarówno opisu i analizy zjawisk współczesnych, jak i historii teatru, zwłaszcza w Polsce niemal całkowicie zdominowanej przez historię teatru dramatycznego. Rozumiem dążenie do wypracowania klarownych podziałów, ale sądzę, że błędem większym niż ich zniszczenie jest zamknięcie się na jakieś zjawiska ze względu na ich domniemaną „nieteatralność”. Niebezpieczeństwo takie towarzyszy jak cień każdemu zawężeniu definicji, toteż zamiast obwarowania się solidnymi murami, proponuję wyjście, otwarcie na różnorodność praktyk i doświadczeń otaczającej nas rzeczywistości.

Czy zatem proponuję zanurzenie się $\mathrm{w}$ performatywnym morzu? Tak, z tym jednak zastrzeżeniem, że zanurzenie nie może oznaczać roztopienia. Istnieje bowiem ryzyko, że przedmiot refleksji teatrologicznej rozmyje się w niekończącej się powodzi "zachowanych zachowan”, że teatr stanie się tylko jednym $\mathrm{z}$ wielu rodzajów performansu. Oznaczałoby to - paradoksalnie - powrót do jego wąskiego rozumienia, co wiąże się z łatwością, z jaką pojęcie „teatr" w jego szerokim rozumieniu jest zastępowane przez o wiele szersze i wygodniejsze w użyciu określenie „performans". Pozwala to na opisywanie pewnych zjawisk charakterystycznych dla teatru jako występujących także poza nim, ale jednocześnie powoduje, że samo pojęcie zostaje ograniczone tylko do pewnego typu przedstawień. Dokładnie rzecz biorąc, użycie nazwy „teatr” ma w praktyce performatyki sens tylko wówczas, gdy nie ma innej, dokładniej opisującej dane zjawisko nazwy, rozstrzyga zaś o tym kontekst kulturowy. I tak na przykład nie ma potrzeby zastanawiać się, czy japońskie nô to teatr, skoro można je opisać jako rodzaj performansu noszący nazwę nô. Wobec tego teatrem pozostaje tylko to, co jest nim w wąskim rozumieniu, a więc „dziedzina sztuki polegająca na realizowaniu scenicznych utworów literackich".

W moim przekonaniu (a ostatecznie tylko o przekonaniach można dziś mówić w naukach humanistycznych) jest to błąd, gdyż termin „teatr" opisuje zjawisko wyróżniające się wśród wielu innych odmian szeroko rozumianego performansu, a zarazem szersze niż tylko właściwa zachodniej kulturze sztuka inscenizowania dramatu. Co ciekawe, sugestię pozwalającą wskazać na podstawę owego wyróżnienia znaleźć można u „ojca” performatyki, Richarda Schechnera, który pisze, że „stać się świadomym zachowanego zachowania, to poznać procesy, dzięki którym procesy społeczne w całej swej różnorodności przemieniają się w teatr. Teatr nie $\mathrm{w}$ wąskim sensie inscenizacji dramatów na scenie [...], ale w szerszym sensie"22. Idąc tym tropem, można dojść do tezy - obecnej też, choć nie bezpośrednio, u Schechnera - że teatr jest szczególnym rodzajem

22 R. Schechner, Co to jest performans, s. 136. 
performansu świadomego - stworzonego według określonych reguł i zasad, i - co wydaje się najważniejsze - oznaczonego jako taki. Sposób tego oznaczania zależy od konwencji i kontekstu, a także od zmian zachodzących w praktyce i ideologii (zarówno twórców jak i odbiorców). Nie jest więc stały i dany raz na zawsze. Jednym, co stałe, jest sam fakt oznaczania, istnienia konwencji pozwalających na skonstruowanie pewnego działania jako teatru. Znaczy to, że definicja tej dziedziny jest w praktyce badawczej zawsze czymś do zdobycia. Znaczy, że naszym zadaniem jako ludzi usiłujących opisać i zrozumieć ten, wciąż wynikający się opisowi i zrozumieniu, fenomen jest każdorazowe podejmowanie na nowo wysiłku zrekonstruowania zasad oznaczania, przy świadomości, że żaden ich zestaw nie jest oczywisty, naturalny i niezmienny. Dynamice teatru odpowiadać powinna dynamika opisu, czyniąca $z$ teatrologa człowieka, który nigdy nie jest $w$, ale zawsze $k u$.

I taki tylko ostatecznie może być sens niezbyt szczęśliwego tytułu tego artykułu. 